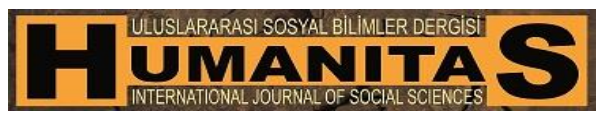

Humanitas, 2017; 5(9): 203-218

ISSN: 2147-088X

http://humanitas.nku.edu.tr

DOI: $\underline{10.20304 / \text { humanitas.318516 }}$

Araştırma-İnceleme

\title{
CONTRIBUTION OF AN ENVIRONMENTAL DOCUMENTARY MOVIE ON THE DEVELOPMENT OF PRE-SERVICE TEACHERS' ENVIRONMENTAL ATTITUDES
}

\author{
Yunus ALYAZ ${ }^{1}$ \\ Ali Osman ÖZTÜRK ${ }^{2}$ \\ Zübeyde Sinem GENÇ ${ }^{3}$
}

\begin{abstract}
This study investigates whether environmental documentaries have an effect on the attitudes of pre-service teachers, who are in an important position to shape coming generations. A total of 76 pre-service teachers at two state universities in Turkey participated in the study and worked on the activities designed about the documentary 'Home'. The RNEP Scale (Dunlap et al., 2000) was used to measure and define the attitudes of pre-service teachers toward environment before and after the activities. The findings of the study showed that working on the environmental documentary had a positive influence since there was a significant difference in the attitude levels of pre-service teachers before and after watching the environmental documentary.The age and gender features of the pre-service teachers did not affect their attitude averages before or after the activity. Nevertheless, significant differences were observed at the sub-dimensions of the scale and at the language proficiency level of the participants. The difference between universities also disappeared after the activities. The difference in the attitudes was progressively significant as the language proficiency level of the participants increased. It is evident that the participants were more anthropocentric than ecocentric although they developed more positive behaviours toward environment after the activities.
\end{abstract}

\footnotetext{
${ }^{1}$ Doç. Dr., Uludağ Üniversitesi, Eğitim Fakültesi, Almanca Öğretmenliği Bölümü. alyaz@uludag.edu.tr

${ }^{2}$ Prof. Dr., Necmettin Erbakan Üniversitesi, Ahmet Keleşoğlu eğitim Fakültesi, Alman Dili Eğitimi Anabilim Dalı. alozturk06@gmail.com

${ }^{3}$ Doç. Dr.,Uludağ Üniversitesi, Eğitim Fakültesi, İngilizce Öğretmenliği Bölümü. zsgenc@uludag.edu.tr
} 
Alyaz, Y. Ve Ark. (2017). Contribution of An Environmental Documentary Movie on The Development of Pre-Service Theachers' Environmental Attitudes. Humanitas, 5(9), 203-218

Keywords: Home, Revised New Ecological Paradigm Scale, NEP, Foreign Language Education, Pre-service Teachers, Environmental Attitude.

\section{ÇEVRE İÇERİKLİ BİR BELGESEL FILMİN ÖĞRETMEN ADAYLARININ ÇEVREYE ILIŞKIN TUTUMLARINA ETKİSI}

Öz: $\mathrm{Bu}$ çalışmada çevre konulu belgesel filmlerin gelecek kuşakları yetiştirmek gibi önemli bir konumda olan öğretmen adaylarının çevreye ilişkin tutumlarına olumlu etkide bulunup bulunmadığı ele alınmaktadır. Çalışmanın örneklemi iki devlet üniversitesinde öğrenim görmekte olan ve 'Home' isimli çevre belgeseliyle yabancı dil öğrenme etkinliklerine katılan 76 öğretmen adayından oluşmaktadır. Öğretmen adaylarının etkinlik öncesinde ve sonrasında çevreye ilişkin tutumlarını belirlemek amacıyla yeni çevresel paradigma ölçeği (Dunlap et al., 2000)kullanılmıştır.Bu çalışmada öğretmen adaylarının belgesel film etkinliği öncesi ve sonrası tutum ortalamaları arasında anlamlı farklılıkelde edildiği bulgusu söz konusu çevre belgeselinin öğretmen adaylarının çevreye ilişkin tutumlarına olumlu katkıda bulunduğunu göstermektedir. Katılımcıların çevreye ilişkin tutum değerleri etkinlik öncesinde ve sonrasında yaş ve cinsiyet gibi değişkenlere göre farklılık göstermemektedir. Ancak katılımcıların dil seviyelerinin ölçeğin alt boyutlarında çevre tutumuna etki ettiği belirlenmiştir. Etkinlik öncesinde katılımcıların tutum değerleri ait oldukları üniversite değişkenine göre farklılık gösterirken etkinlik sonrasında fark belirlenmemiştir. Katılımcıların çevreye ilişkin tutumlarının etkinlik sonrasında daha olumlu olmasına karşın bu olumlu tutumlarının çevre merkezli olmaktan çok insan merkezli olduğu belirlenmiştir.

Anahtar Sözcükler: Home, Yeni Çevresel Paradigma Ölçeği, NEP, Yabancı Dil Eğitimi, Öğretmen Adayları, Çevreye İlişkin Tutum.

\section{Introduction}

Environment has become the focus of attention in the world's agenda due to the global warming, depletion of natural resources, environmental deterioration, extreme diseases caused by environmental disasters and many other environmental problems that have emerged duringthe last decades. As a result, many researchers, local, national and international institutions focused on the conditions for environmental quality or environmental concern as stated clearly in the early reports of the World Commission on Environment and Development (WCED, 1987) and in the United Nations Environment Program (UNEP, 2005). Although there has been relatively increasing awareness as a consequence of environmental problems, humans are not immune to ecological constraints and future generations and the ecosystem IS are in danger (Erdogan, 2009; Erten, 2012; Toth, 2010; Verdugo\&Armendáriz, 2008). The fact that environmental problems present a serious and global threat which needs urgent and total action has been accepted not only byresearchers and international authorities but also by specialists in literature and philosophy as a highly-voiced topic. 
It is generally agreed that change comes about if people develop positive attitudes and in this regard it is clear that the need for education to make people aware of their negative impact on nature could only be realized through effective environmental education in primary, secondary, tertiary and higher levels and both in formal and non-formal settings, as stated in the 10 Point Action Plan of the Tallores Declaration of the Association of University Leaders for a sustainable Future (AULSF, 1990). The Bologna Process (Sustainable Bologna, 2005) calls for an urgent need for sustainability education in interdisciplinary, transdisciplinary and multidisciplinary contexts as well.Although the causes of the environmental problems and their solutions are complex and multidimensional, two main views concerning the environmental problems have arisen: Many researchers (e.g.Wolf-Watz,Sandell, \&Fredman, 2011) argue that human activities such as technological developments, mode and relations of industrial production, distribution and consumption are responsible for the ecological crisis while others (e.g. Dunlap \& Van Liere, 1978) claim that the beliefs, values and attitudes of humans caused these problems. Yet, both of these views accept that people should immediately change their attitudes toward the environment to solve environmental problems.

It is believed that individuals' socio-demographic attributes such as gender, age, education type and level, environmental education, nature connectedness, family structure, religious beliefs, political preferences, family income, ethnicity and many other variables involved may have an influence on their attitudes towards environmental issues in varying degrees. However, age, gender and educational concerns (such as education type and level, scientific knowledge) have been the most studied variables predicting people's environmental concern. Yet, the research results indicate inconsistency in respect to these three socio-demographic variables (Aytaç\&Öngen, 2012; Casey and Scott, 2006; Dunlap et al., 2000; Sam et al., 2010; Shephard et al. 2009; Weber, 2011). Many other socio-demographic variables were also considered to be influential on attitudes such as academic major, country, ethnic origin, religious beliefs, political tendencies, etc. Similarly, the findings from research investigating such alternative variables presented a scattered pattern.

As Brämer (2006) stated, young generation lives in a digital media-dominated age and grows distanced from nature and is less concerned for the environment. According to the previous research focusing on a diverse array of variables, environmental education and nature connectedness have proven to be the most consistent in their relationship to the levels of environmental concern. The studies investigating the effects of environmental education (Ewert and Baker, 2001) and/or attending outdoor activities (e.g. Bauer, 2006; Karlegger, 2010; Stern et al., 2008; Wolf-Watz et al., 2011) have displayed a positive relationship between these two factors and pro-environmentalism. Other Turkish and crosscultural studies showed that environmental education, amateur nature activities and professional outdoor sports (Ardahan 2012; K1liç\&İnal, 2010; Boeve-De Pauw\& Van Pategem, 2012) proved to be the most effective ways of 
Alyaz, Y. Ve Ark. (2017). Contribution of An Environmental Documentary Movie on The Development of Pre-Service Theachers' Environmental Attitudes. Humanitas, 5(9), 203-218

establishing positive attitudes and behaviours. Moreover, Anderson et al. (2007) and Rowe (2002) report that a single environmental course has an impact on changing students' attitudes toward the environment in a positive way.

In addition, despite the fact that the Common European Framework (CEF) suggests "environment" and "nature" as basic parts of the foreign language teaching curriculum and movies of any kind, including documentaries, as permanent components, they are still not widely considered as canonical parts of language teaching in Turkey, and even in many developed countries for foreign language teachers and educational institutions (Leitzke-Ungerer, 2009; Seeger, 2011) due to the lack of a number of instructional, physical, financial, and logistical factors (Toth, 2010). Studies on the use of film material in foreign language education show that feature films are dominantly used and preferred, besides developing language skills for transmitting cultural content and exchanging cross-cultural values (Seferoğlu, 2008; Zenginvd. 2015). In fact, the potentials of environmental documentary movies, such as increasing environmental values and attitudes in addition to developing linguistic skills are accepted theoretically and suggested by some researchers (Küchler, 2009; Melin, 2013) and language institutions, e.g. CEF. The distribution of the articles reviewed illustrate that environment has been a topic of research mostly in biology and environmental engineering, and show that "environmental documentary movies" have been covered neither within the framework of teaching foreign languages including English nor in environmental education (Küchler, 2009).

The current study reports on the partial data of the second step of a three-year research project on using environmental documentary movies in foreign language teaching, started in 2012 in the department of Foreign Languages Education (German, French and English) at two state universities in Turkey to determine, benchmark and aid developing the language skills, the environmental values and the attitudes of pre-service teachers of foreign languages. In the first step of the project 15 documentaries were selected, analysed and usedby German preparatory students and pre-service German teachers as in- and out-of-class activities during 2013 academic year. In the second step, during the 2014-2015 academic year, one of the movies, 'Home' (Arthus-Bertrand, 2009), for which two exercise books were prepared at the B1 and $\mathrm{C} 1$ levels for the viewing and listening skills, was used with pre-service teachers in two universities.

\section{Method}

\subsection{Research Design}

The study employed a quantitative research design since a scale was used to measure the attitudes of the participants. The quantitative research design was chosen because the study aimed to determine if there were significant differences between groups investigated.Furthermore, because the quantitative design is more reliable and objective, the subjectivity of researcher in 
Alyaz, Y. Ve Ark. (2017). Contribution of An Environmental Documentary Movie on The Development of Pre-Service Theachers' Environmental Attitudes. Humanitas, 5(9), 203-218

methodology is recognized less (Daniel, 2010), which constitutes the main reason why this research design was preferred for the study.

\subsection{Research Sample}

The participants were a total of 76 pre-service teachers (61 female, 15 male) from two state universities in Turkey. The range of pre-service teachers' ages was between 19-36 years- (average: 22) they were in their second year at the department of German language teaching and their language proficiency level varied between $\mathrm{A} 2$ and $\mathrm{C} 1+$ at the time of data collection. The participants had not received education on environment, and they had not watched any environmental documentaries before.

\subsection{Research Instruments and Procedure}

The Turkish version of the Revised New Ecological Paradigm Scale (Dunlap, et al. 2000) was used in the present study. The New Ecological Paradigm (NEP) was originally developed by Dunlap \& Van Liere (1987). Their assumption contradicted the traditional sociological view which proposed that humanenvironmental relationships were not important sociologically because humans were 'exempt' from environmental forces via cultural change. This traditional view was highly criticized within the framework of the Human Exemptionalism Paradigm (HEP).Hence, NEP and the RNEP adopted a fully new approach which took environmental variables into full account and considered humans as a part of nature. The NEP (Dunlap \& Van Liere, 1978) and RNEP (Dunlap, et al. 2000), and some other scales derived from NEP (Verdugo\&.Armendáriz 2008; Oliveira et al., 2012) have been widely used by many researchers as attitude measures. Although there are many research tools to record the conceptions and attitudes of individuals or groups, the RNEP has been widely used successfully in the last decades to measure, classify, and better understand the values, attitudes and ecological worldviews of the individuals or groups in respect of a variety of socio-demographic attributes. The RNEP scale was translated into Turkish and its validity and reliability tests were made by Erdogan (2009). The Turkish version of RNEP has also been used widely by many researchers such as Ardahan (2012), Aytaç\&Öngen (2012), Demirel et al. (2009) and many others. Thus, the Turkish version of the RNEP was chosen for the present study. The revised NEP scale consists of 15 items that relate to five sub-dimensions (fragility of nature's balance, possibility of eco-crisis, antianthropocentrism, anti-exemptionalism, and limit to growth).

The data were collected through the Revised New Ecological Paradigm Scale (Dunlap, et al. 2000) in a classroom context in the fall semester of the 20142015 academic year at two state universities before and after the environmental movie activity.The movie 'Home' (Arthus-Bertrand, 2009) was chosen as course material for the purposes of the present study because it efficiently presents the history, current and future status of environmental problems, and because it has been dubbed in many languages as a nonprofitable movie. The documentary movie activity was designed to last 14 
weeks ( 2 hours/week). In class, the participants were expected to watch the movie and be involved in question-answer sessions on its content. They also worked on the 'watch, comprehend and read' activities prepared. Out of class, they were asked to prepare small-scale research papers on environment written in their foreign language.

\subsection{Data Analysis}

Primarily, a t-test was applied in order to determine whether there was a significant difference in the level of the participants' attitudes toward environment before and after the project. ANOVA test was applied to specify the descriptive values of the attitude averages for the items and sub-dimensions of the scale, and Scheffe test was applied to identify the differences between sub-dimensions. In this study, the differences in the pre-service teachers' attitudes in terms of affiliation, gender, age and language level were identified by using t- test for paired-samples comparisons and ANOVA for multiple comparisons. The reliability coefficient (Alpha) was .80 for pre-test and .76 for post-test.

\section{Results}

A paired-samples t-test was applied to observe whether there was a significant difference in the attitude averages of the pre-service teachers before and after the activity with the environmental documentary.

Table 1. Comparison of the attitude averages of pre-service teachers before and after the activity

\begin{tabular}{lcccccc}
\hline Measurement & $\mathrm{N}$ & $\mathrm{M}$ & $\mathrm{SD}$ & $\mathrm{df}$ & $\mathrm{t}$ & $\mathrm{p}$ \\
\hline Pre-Test & 76 & 3,5 & 0,48 & 75 & $-7,30$ & 0,000 \\
Post-Test & 76 & 3,7 & 0,57 & & &
\end{tabular}

As seen in Table 1 , there was a significant difference $(\mathrm{t}(75)=-7,30, \mathrm{p}<0,01)$ in pre-service teachers' attitude averages before the project $(\mathrm{M}=3,4 ; \mathrm{SD}=, 48)$ and after the project $(\mathrm{M}=3,7 ; \mathrm{SD}=, 57)$.

The five sub-dimensions of the scale 'fragility of nature's balance, possibility of eco-crisis, anti-anthropocentrism, anti-exemptionalism, and limit to growth' were analysed to see if there was a significant difference in the attitude averages of the participants before and after the project. Table 2 reports the descriptive statistics for the Scale.

Table 2. Descriptive statistics of the attitude averages for the sub-dimensions

\begin{tabular}{lccccc}
\hline Sub-dimension & N & \multicolumn{2}{c}{ Pre-Test } & \multicolumn{2}{c}{ Post-Test } \\
& & M & SD & M & SD \\
\hline Fragility of nature's balance & 76 & 3,67 & 0,76 & 3,86 & 0,58 \\
Possibility of eco-crisis & 76 & 3,88 & 0,95 & 4,42 & 0,55
\end{tabular}


Alyaz, Y. Ve Ark. (2017). Contribution of An Environmental Documentary Movie on The Development of Pre-Service Theachers' Environmental Attitudes. Humanitas, 5(9), 203-218

\begin{tabular}{llllll} 
Anti-anthropocentrism & 76 & $\mathbf{3 , 1 7}$ & 0,74 & $\mathbf{3 , 3 9}$ & 0,64 \\
Anti-exemptionalism & 76 & 3,43 & 0,84 & 3,58 & 0,74 \\
Limit togrowth & 76 & $\mathbf{3 , 1 6}$ & 0,82 & $\mathbf{3 , 4 7}$ & 0,77 \\
\hline
\end{tabular}

The attitude averages of the participants increased in all 5 sub-dimensions after the project. The 'possibility of eco-crisis' $(\mathrm{M}=3,88)$ had the highest average before the activity. The 'fragility of nature's balance' $(M=3,67)$, 'antiexemptionalism' $(\mathrm{M}=3,43)$, and 'anti-anthropocentrism' $(\mathrm{M}=3,17)$ followed respectively. The lowest attitude average was observed in the 'limit to growth' $(M=3,16)$. The results of the post-test revealed an increase in the attitude averages in all sub-dimensions.

ANOVA was applied in order to identify a significant difference between preand post-test scores of the sub-dimensions in the Scale. The results for the 'fragility of nature's balance' are shown in Table 3.

Table 3. Results for pre- and post-test scores of 'Fragility of nature's balance'

\begin{tabular}{lcccccc}
\cline { 1 - 4 } Variance & Sum of Squares & df & Mean Square & $\underline{\mathrm{F}}$ & $\mathrm{p}$ \\
Between Groups & 28,05 & 7 & 4,00 & 16,98 & 0,000 \\
Within Groups & 16,05 & 68 & 0,23 & & \\
Total & 44,09 & 75 & & & \\
\hline
\end{tabular}

There was a significant difference between the mean scores of pre-test $(\mathrm{M}=3,67)$ and post-test scores $(\mathrm{M}=3,86)$ of the participants' attitude for 'Fragility of Nature's Balance' ( $F(7-68)=16,98 ; \mathrm{p}<0,05)$.

The results of pre-test and post-test attitude means of the participants for 'Possibility of an eco-crisis' are shown in Table 4.

Table 4. Results for pre- and post-test scores of 'Possibility of an eco-crisis'

\begin{tabular}{lccccc}
\hline Variance & Sum of Squares & df & Mean Square & F & p \\
\hline Between Groups & 18,17 & 6 & 3,03 & 4,146 & 0,001 \\
Within Groups & 50,39 & 69 & 0,73 & & \\
Total & 68,56 & 75 & & & \\
\hline
\end{tabular}

There was a significant difference between the mean scores of pre- $(M=11,65)$ and post-tests $(M=13,28)$ of the participants' attitudes toward the 'Possibility of an Eco-crisis' $(\mathrm{F}(6-69)=4,146 ; \mathrm{p}<0,05)$.

The results of pre-test and post-test in the participants' attitude means in the 'anti-anthropocentrism' are presented in Table 5.

Table 5. Results for pre- and post-test scores of 'Anti-anthropocentrism'

\begin{tabular}{lllllll}
\hline Variance & Sum of Squares & df & Mean Square & $F$ & $p$ \\
\hline
\end{tabular}


Alyaz, Y. Ve Ark. (2017). Contribution of An Environmental Documentary Movie on The Development of Pre-Service Theachers' Environmental Attitudes. Humanitas, 5(9), 203-218

\begin{tabular}{lccccc}
\hline Between Groups & 19,55 & 8 & 2,44 & 7,40 & 0,000 \\
Within Groups & 22,12 & 67 & 0,33 & & \\
Total & 41,66 & 75 & & & \\
\hline
\end{tabular}

There was a significant difference between the mean scores of pre-test $(\mathrm{M}=3,17)$ and post-test $(\mathrm{M}=3,39)$ of participants' attitudes in the 'Antianthropocentrism' $(\mathrm{F}(8-67)=7,40 ; \mathrm{p}<0,05)$.

The results of pre-test and post-test attitude means of participants in the 'antiexemptionalism' are shown in Table 6.

Table 6. Results for pre-test and post-test scores of 'Anti-exemptionalism'

\begin{tabular}{lccccc}
\hline Variance & Sum of Squares & df & Mean Square & F & p \\
\hline Between Groups & 30,09 & 9 & 3,34 & 9,38 & 0,000 \\
Within Groups & 23,50 & 66 & 0,35 & & \\
Total & 53,60 & 75 & & & \\
\hline
\end{tabular}

There was significant difference between the mean scores of pre-test $(M=3,43)$ and post-test scores $(\mathrm{M}=3,58)$ of participants' attitudes toward 'antiexemptionalism' $(\mathrm{F}(7-66)=9,38 ; \mathrm{p}<0,05)$.

The results of 'limit to growth' are reported in Table 7.

Table 7. ANOVA results for pre-test and post-test scores in 'Limit to growth'

\begin{tabular}{lccccc}
\hline Variance & Sum of Squares & df & Mean Square & F & p \\
\hline Between Groups & 308,39 & 9 & 34,26 & 14,82 & 0,000 \\
Within Groups & 152,60 & 66 & 2,31 & & \\
Total & 461,00 & 75 & & & \\
\hline
\end{tabular}

There was significant difference between the mean scores of pre-test $(M=3,16)$ and post-test scores $(M=3,47)$ of participants' attitudes regarding 'antiexemptionalism' $(\mathrm{F}(9-66)=14,82 ; \mathrm{p}<0,05)$.

Each item in the Scale was analyzed as well. Table 8 shows the mean scores of pre-test and post-test for every single item.

Table 8. Descriptive statistics of each item's pre- and post-test attitude scores

NEP Items

1. We are approaching the limit of the number of people the earth can support.

2. Humans have the right to modify the natural $\quad 3,39 \quad 1,341 \quad 3,47 \quad 1,266$ environment to suit their needs.

Pre-Test Post-Test

Mean SD Mean SD

$3,12 \quad 1,469 \quad 3,95 \quad 1,210$ 
Alyaz, Y. Ve Ark. (2017). Contribution of An Environmental Documentary Movie on The Development of Pre-Service Theachers' Environmental Attitudes. Humanitas, 5(9), 203-218

3. When humans interfere with nature it often produces disastrous consequences. 4. Human ingenuity will ensure that we do NOT $3,09 \quad 1,122 \quad 3,25 \quad 1,212$ make the earth unliveable.

5. Humans are severely abusing the environment

$3,87 \quad 1,193 \quad 4,67 \quad 598$

6. The earth has plenty of natural resources if we $\mathbf{2 , 6 7} \quad 1,025 \quad \mathbf{2 , 7 2} \quad 1,250$ just learn how to develop them.

7. Plants and animals have as much right as $3,66 \quad 1,475 \quad 4,49 \quad, 577$ humans to exist.

8. The balance of nature is strong enough to cope with the impacts of modern industrial nations.

9. Despite our special abilities humans are still subject to the laws of nature.

10. The so-called "ecological crisis" facing humankind has been greatly exaggerated.

11. The earth is like a spaceship with very limited room and resources.

12. Humans were meant to rule over the rest of nature.

13. The balance of nature is very delicate and easily upset.

14. Humans will eventually learn enough about how nature works to be able to control it.

15. If things continue on their present course, we $3,72 \quad 1,343 \quad 4,37 \quad, 690$ $3,21 \quad 1,351 \quad 3,53 \quad 1,170$ $3,66 \quad 1,078 \quad 4,28 \quad, 759$ $3,83 \quad 1,171 \quad 3,96 \quad 1,125$ $3,71 \quad 935 \quad 3,76 \quad, 936$ $\mathbf{2 , 3 8} \quad 1,265 \quad \mathbf{2 , 2 9} \quad 1,153$ 211 will soon experience a major ecological catastrophe.

The participants' attitudes for each item before and after the project were above the average except for the items 6 and 12(M=3,00). Item 15 had the highest pretest $(M=3,96)$ and post-test $(M=4,66)$ scores.

The study investigated whether other demographic factors had an effect on the attitudes before and after the project. An independent-samples t-test was conducted to evaluate whether there was a statistical difference between the mean values of pre-test scores of 17 participants from university $1(\mathrm{M}=3,03)$ and 14 participants from university $2(\mathrm{M}=3,59)$. Test results are shown in Table 9. 
Alyaz, Y. Ve Ark. (2017). Contribution of An Environmental Documentary Movie on The Development of Pre-Service Theachers' Environmental Attitudes. Humanitas, 5(9), 203-218

Table 9. Independent-samples t-test table for comparison of pre-test results of participants from two universities

\begin{tabular}{lcccccc}
\hline Groups & $\mathrm{N}$ & $\mathrm{M}$ & $\mathrm{SD}$ & $\mathrm{df}$ & $\mathrm{t}$ & $\mathrm{p}$ \\
\hline University 1 & 17 & 3,03 & 0,33 & 74 & $-3,83$ & 0,000 \\
University 2 & 59 & 3,59 & 0,57 & & & \\
\hline
\end{tabular}

The results indicated that there was a significant difference between pre-test scores of the two groups $(\mathrm{t}(74)=-3,83, \mathrm{p}<0,05)$. The difference worked in University 2's favour.

Independent-samples t-test results of the post-test regarding the affiliation are shown in Table 10.

Table 10. Independent-samples t-test table for comparison of post-test results of participants from two universities

\begin{tabular}{lcccccc}
\hline Groups & $\mathrm{N}$ & $\mathrm{M}$ & $\mathrm{SD}$ & $\mathrm{df}$ & $\mathrm{t}$ & $\mathrm{p}$ \\
\hline University 1 & 17 & 3,64 & 0,38 & 74 & $-1,03$ & 0,142 \\
University 2 & 59 & 3,77 & 0,50 & & & \\
\hline
\end{tabular}

The results indicated that there was no significant difference between post-test scores of the groups, $\mathrm{t}(74)=-1,03, \mathrm{p}>0,05$.

The study examined whether the attitude averages of the participants from two universities differed according to their gender, age and language level.An independent-samples t-test was conducted to evaluate whether there was a statistical difference between the mean attitude values of pre-test scores of females and males. The results are shown in Table 11.

Table 11. Independent-samples t-test table for comparison of pre-test scores of gender groups

\begin{tabular}{lcccccc}
\hline Groups & $\mathrm{N}$ & $\mathrm{M}$ & $\mathrm{SD}$ & $\mathrm{df}$ & $\mathrm{T}$ & $\mathrm{P}$ \\
\hline Female & 60 & 3,42 & 0,54 & 74 & $-1,163$ & 0,053 \\
Male & 16 & 3,70 & 0,70 & & & \\
\hline
\end{tabular}

There was no significant difference between pre-test scores of 60 females $(\mathrm{M}=3,42)$ and 16 males $(\mathrm{M}=3,70), \mathrm{t}(74)=-1,163 ; \mathrm{p}>0,05)$.

An independent-samples t-test was conducted to evaluate whether there was a statistical difference between the mean attitude values of post-test scores of females and males. The post-test results of females and males are shown in Table 12.

Table 12. Independent-samples t-test results for comparison of post-test scores of gender groups 
Alyaz, Y. Ve Ark. (2017). Contribution of An Environmental Documentary Movie on The Development of Pre-Service Theachers' Environmental Attitudes. Humanitas, 5(9), 203-218

\begin{tabular}{lcccccc}
\hline Groups & $\mathrm{N}$ & $\mathrm{M}$ & $\mathrm{SD}$ & $\mathrm{df}$ & $\mathrm{T}$ & $\mathrm{P}$ \\
\hline Female & 60 & 3,70 & 0,46 & 74 & $-1,544$ & 0,384 \\
Male & 16 & 3,91 & 0,53 & & & \\
\hline
\end{tabular}

There was no significant difference between post-test scores of 60 females $(\mathrm{M}=3,70)$ and 16 males $(\mathrm{M}=3,91), \mathrm{t}(74)=-1,544 ; \mathrm{p}>0,05)$.

ANOVA was applied to evaluate the effects of age on the mean pre-test and post-test values of the groups. The pre-test results are shown in Table 13.

Table 13. ANOVA results for comparison of pre-test scores of age groups

\begin{tabular}{lccccc}
\hline Variance & Sum of Squares & df & Mean Square & $\mathrm{F}$ & $\mathrm{p}$ \\
\hline Between Groups & 3,123 & 8 & 0,39 & 1,206 & 0,309 \\
Within Groups & 21,68 & 67 & 0,33 & & \\
Total & 24,809 & 75 & & & \\
\hline
\end{tabular}

The post-test results regarding the age groups are illustrated in Table 14.

Table 14. ANOVA results for comparison of post-test scores of age groups

\begin{tabular}{lccccc}
\hline Variance & Sum of Squares & df & Mean Square & F & $p$ \\
\hline Between Groups & 2,679 & 8 & 0,34 & 1,531 & 0,163 \\
Within Groups & 14,662 & 67 & 0,22 & & \\
Total & 17,341 & 75 & & & \\
\hline
\end{tabular}

The results of ANOVA in Tables 13 and 14 indicated that there was no significant difference among the mean attitude scores of pre-test $(\mathrm{F}(8$ $67)=1,206, p>0,05)$ and post-test results $(F(8-67)=1,531, p>0,05)$ of age groups. In order to determine whether the participants' language level had any effect on the attitudes before and after the project, ANOVA was conducted to test the pretest scores of participants having level A2, B1, B2 and C+. The pre-test results are shown in Table 15.

Table 15. ANOVA results for comparison of pre-test scores of language levels

\begin{tabular}{lccccc}
\hline Variance & Sum of Squares & df & Mean Square & $\mathrm{F}$ & $\mathrm{p}$ \\
\hline Between Groups & 3,473 & 3 & 1,16 & 3,906 & 0,012 \\
Within Groups & 21,336 & 72 & 0,29 & & \\
Total & 24,809 & 75 & & & \\
\hline
\end{tabular}

There was a significant difference in attitude averages between the group of 6 participants at A2 level $\mathrm{M}=3,05$ ) and the group of 5 participants at $\mathrm{C}+$ level $(\mathrm{M}=3,5)$ The difference worked in favour of the $\mathrm{C}+$ group. 
Alyaz, Y. Ve Ark. (2017). Contribution of An Environmental Documentary Movie on The Development of Pre-Service Theachers' Environmental Attitudes. Humanitas, 5(9), 203-218

The post-test results of language level groups are shown in Table 16.

Table 16. ANOVA results for comparison of post-test scores of language levels

\begin{tabular}{lccccc}
\hline Variance & Sum of Squares & df & Mean Square & F & p \\
\hline Between Groups & 2,459 & 3 & 1,16 & 3,965 & 0,011 \\
Within Groups & 14,882 & 73 & 0,29 & & \\
Total & 17,341 & 75 & & & \\
\hline
\end{tabular}

There is a significant difference in the attitude averages between the six A2 level participants $(M=3,46)$ and the 5 participants at $C+$ level $(M=3,5)$, in favour of the group $\mathrm{C}+$. A significant difference was observed between 55 participants at $B 1$ level $(M=3,71)$ and the average level of the group at $\mathrm{C}+$ level $(M=3,5)$, in favour of the group B1 $(\mathrm{F}(3-72)=3,965, \mathrm{p}<0,05)$.

\section{Discussion, Conclusionsand Recommendations}

Working with the environmental documentary affected pre service teachers' attitudes about environment in a positive way. The significant difference between pre- and post-film activities shows that the attitude averages of the participants increased. Intensive work with an environmental documentary positively developed pre-service teachers' attitudes toward environment. This is an anticipated conclusion for the purposes set out in this study. This conclusion is consistent with Anderson et al. (2007) and Rowe (2002), whostatethat there is evidence that a single environmental course has an impact on changing students' attitudes and behaviours toward the environment in a positive way. This indicates that the integration of an environmental documentary into a course syllabus works for the positive attitudes of the target population as well as a comprehensive environmental education program.

The results concerning the sub-dimensions of the scale are collinear with the results when the scale was measured as a whole. In other words, the attitude averages of the participants increased in all 5 sub-dimensions after the project and there was a significant difference between the attitudes before and after the (project). However, the sub-dimensions 'limit to growth' (items 1, 6, 11) and 'anti-anthropocentrism' (items 2, 7, 12) had the lowest figures before and after the implementation of the project (as highlighted in Table 2). This result indicates that pre-service teachers hold traditional conceptions such as the risk of endangered natural resources, over-population (limit to growth), considering human beings as the masters and the rightful owners of nature to utilize it for their own needs (anti-anthropocentrism) although they have developed positive attitudes toward environment. That is to say the environmentally friendly attitude is grounded on the fundamental principle that humanity gets the full value of nature. This shows that the underlying reason for an environmentally friendly attitude is based on the advantage that human beings would take from the environment. 
The results of the item analysis revealing that the positive attitude of the preservice teachers is not ecocentric (protecting nature for its sake) but anthropocentric (protecting nature to make use of it) are shown inTable 8. This creates a situation in which the participants believe that human beings' having a disproportionate relation with nature would cause an eco-crisis on a global scale, which does not seem to prevent human beings from rejecting their high positions in nature (Erdogan 2009, Erten 2012). This sample corresponds with the behavioural traits of even the most educated/conscious people, who, after spending some time reading news about natural disasters, do tend towards reading happy news in order to get rid of the negative aspect of the former news.

According to the findings of the research, there was a difference between the attitude levels of the participants from two public universities before the research was conducted. However, after the project increasing the attitude levels, there was no significant difference among the groups' attitude levels. It has been shown that demographic variables such as gender and age did not have an impact on the average attitude levels in most of the researches conducted before (Aytaç\&Öngen, 2012; Casey and Scott, 2006; Sam et al., 2010; Shephard et al., 2009; Weber, 2011). This study, as well, proved that demographic variables did not influence participants' attitudes towards the environment before or after the documentary movie activity.

It has been found out that the pre- \& post-test attitude averages of the participants varied significantly according to their language levels. It is thought that the underlying reason for the difference is not the level of the participants but the personal characteristics of the participants and other variables which caused a rise in the attitude levels. There had not been any research on using documentaries in language teaching before. There may be further research on integrating environmental documentaries and consciousness-raising activities into language classes so as to extend the use of documentary film in foreign language teaching. The results between the studies may be compared to shed more light on the study.

\section{References}

Anderson, M. W.,Teisl, M., F., Criner, G., K., Tisher, S., Stewart, S. Hunter, M., L. andNorton, S., A.(2007). Attitudechange of undergraduatestudents in general educationcourses. Journal of General Education, 56(2), 149-168. doi: 10.1353/jge.2007.0016

Ardahan, F.(2012). Comparison of the New EcologicalParadigm (NEP) Scale's Level of Participants and NonParticipant of Outdoor Sports withRespecttoSomeDemographicVariables: Turkey Case. The Online Journal of RecreationandSport, 1(3), 8-18.

Arthus-Bertrand, Y. (2009). Home, Documentary Movie [Blu-Ray Disk]. France: FondationGoodplanet. 
Alyaz, Y. Ve Ark. (2017). Contribution of An Environmental Documentary Movie on The Development of Pre-Service Theachers' Environmental Attitudes. Humanitas, 5(9), 203-218

Aytaç, M. andÖngen, B. (2012). Doğrulayıcı faktör analizi ile yeni çevresel paradigma ölçeğinin yapı geçerliliğinin incelenmesi, İstatistikçiler Dergisi 5, 14-22.

Bauer, J.(2006). Perspektivübernahme mit zukünftigenGenerationenalsMittel, umweltschützendesVerhaltenzuerhöhen - ein Experiment, Unpublished Diploma Thesis, Friedrich-Alexander-Universität. Retrievedfrom http://kmgne.de/wp-content/uploads/2013/05/judithbauer2006.pdf.

Boeve-De Pauw, J. andVanPategem, P.(2012). CulturalDifferences in theEnvironmentalWorldview of Children, International Electronic Journal of EnvironmentalEducation, 2(1), 1-12.

Brämer, R.(2006). Naturobskur. WieJugendlicheheuteNaturerfahren. München: oekom.

Casey, P.,J. Ve Scott, K. (2006). Environmentalconcernandbehaviour in an Australiansamplewithin an ecocentric-anthropocentricframework. AustralianJournal of Psychology, 58(2), 57-67. doi: $10.1080 / 00049530600730419$.

Daniel, M. (2010). DoingQuantitativeResearch in Educationwith SPSS. 2nd Edition. London: SAGE Publications.

Demirel, M., Gürbüz, B. andKaraküçük, S. (2009). Rekreasyonel Aktivitelere Katılımın Çevreye Yönelik Tutum Üzerindeki Etkisi ve Yeni Ekolojik Paradigma Ölçeği' nin Geçerliği ve Güvenirliği, Spormetre, 7(2), 47-50.

Dunlap, R. and Van Liere, K. (1978). The 'New Environmental Paradigm': A proposed measuring instrument and preliminary results. Journal of Environmental Education, 9, 10-19. doi: 10.1177/ 0013916595276001

Dunlap, R. E., Van Liere, K., Mertig, A. and Jones, R. (2000). New trends in measuring environmental attitudes: Measuring endorsement of the new ecological paradigm: A revised NEP Scale. Journal of Social Issues, 56(3), 425-442. doi: 10.1111/0022-4537.00176

Erdoğan, N. (2009). Testing the new ecological paradigm scale: Turkish case. African Journal of Agricultural Research, 4(10), 1023-1031.

Erten, S. (2012). Türkve Azeri ÖğretmenAdaylarındaÇevreBilinci, EğitimveBilim, 37(166), 88-100.

Ewert, A. andBaker, D. (2001). Standing for Where You Sit: An Exploratory Analysis of the Relationship between Academic Major and Environment Beliefs. Environment andBehavior, 33, 687-707. doi: 10.1177/00139160121973197

Karlegger, A. (2010). Naturverbundenheit und Umweltidenitität im Jugendalter - Der Einfluss von Naturkontakt und sozialem Kontext. UnpublishedMaster's Thesis. Universität Wien. 
Kılıç, S. andİnal, M. E. (2010). YüksekÖğretimdeÇevreEğitimi Alan veAlmayanÖğrencilerdeÇevreBilinci: NiğdeÜniversitesiÖrneği. NiğdeUniversitesi I.I.B.F Dergisi, 3(2), 70-83.

Küchler, U. (2009). Screening the Green, Greening the Screen. In. E. LeitzkeUngerer, E. (Ed.) Film im Fremdsprachenunterricht - Literarische Stoffe, interkulturelle Ziele, mediale Wirkung (pp. 359-378). Stuttgart: ibidem.

Leitzke-Ungerer, E. (2009). Film im Fremdsprachenunterricht: Herausforderungen, Chanchen, Ziele. In E. Leitzke-Ungerer, (Ed.), Film im Fremdsprachenunterricht - Literarische Stoffe, interkulturelle Ziele, mediale Wirkung (pp. 327-342). Stuttgart: ibidem.

Melin, C. (2013) Climate Change: A "Green" Approach to Teaching Contemporary Germany, Die Unterrichtspraxis/Teaching German 46(2), p. 185-199.

Oliveira, A., W. Akerson, V. L., andOldfield, M. (2012). Environmental Argumentation as Sociocultural Activity, Journal of Research in Science Teaching, 49(7), 869-897.

Rowe, D. (2002). Environmental Literacy and Sustainability as Core Requirements: Success Stories and Models. In. W. L. Filho, (Ed.), Teaching Sustainability at Universities (pp. 79-103). Frankfurt: Peter Lang.

Sam, N., Sam R., andÖngen K. B. (2010), ÜniversiteÖğrencilerininÇevreselTutumlarınınYeniÇevreselParadigmav eBenlikSaygısıÖlçeği İle İncelenmesi, AkademikBakış, 21, 1-16.

Seeger, I. (2011). Exploring Film as EFL Coursebook Supplements and Motivational Stimulus: A German Secondary School Case Study. Unpublished Dissertation. University of Birmingham.

Seferoğlu, G. (2008). Using feature films in language classes, Educational Studies, 34(1), 1-9. doi: 10.1080/03055690701785202

Shephard, K., Mann, S., Smith, N. andDeaker, L. (2009). Benchmarking the environmental values and attitudes of students in New Zealand's post-compulsory education. Environmental Education Research, 15(5), 571-587. doi: 10.1080/13504620903050523

Stern, M., J., Powell, R., B. andArdoin, N., M. (2008). What Difference Does It Make? Assessing Outcomes from Participation in a Residential Environmental Education Program. Journal of Environmental Education, 39(4), 31-44. doi: 10.3200/JOEE.39.4.31-43

Sustainable Bologna (2005). Empfehlungen zur Implementierung der Bildung für nachhaltige Entwicklung im Bologna Prozess. Retrieved from http://assets.wwf.ch/downloads/nachhaltiges bolognad.pdf. 
Alyaz, Y. Ve Ark. (2017). Contribution of An Environmental Documentary Movie on The Development of Pre-Service Theachers' Environmental Attitudes. Humanitas, 5(9), 203-218

Toth, C. A. (2010) Verstehen durch Hören und Sehen - Potenzial und Einsatz authentischer Spielfilme im Unterricht Deutsch als Fremdsprache. Unpublished Dissertation. Universität Wien.

ULSF (1990). TheTalloriesDeclaration. 10 Point Action Plan. Retrievedfrom http://www.ulsf.org/ pdf/TD.pdf.

UNEP (2005). United Nations Environment Programme (UNEP) Strategy for Environmental Education and Training - A Strategy and Action Planning for the Decade 2005 - 2014. Retrieved from www.unep.org/Training/docs/strat_full.pdf 08.08.2014.

Verdugo, C. andArmendáriz (2008). The "New Environmental Paradigm" in a Mexican Community, The Journal of Environmental Education, 31(3), 25-31. doi: 10.1080/00958960009598642

WCED (1987). Report of the World Commission on Environment and Development: Our Common Future. Retrieved from www.undocuments.net/wced-ocf.htm.

Weber, K. (2011). Vertrauen in Effizienz-Technologien und dessen Einfluss auf das Gefühl, einem suffizienten Lebensstil verpflichtet $\mathrm{zu}$ sein. UnpublishedDiploma Thesis, Universität Wien.

Wolf-Watz, D.,Sandell, K. andFredman, P. (2011). Environmentalism and Tourism Preferences: A Study of Outdoor Recreationists in Sweden. Scandinavian Journal of Hospitality and Tourism, 11(2), 190-204. doi: 10.1080/15022250.2011.583066.

Zengin, B., Doğan, D. and Çubukçu, F. (2015). English Major Students'Attitudes towards Moviesand Series as LanguageLearning Resources. VehbiTürel (Ed.). Intelligent Design of Interactive Multimedia Listening Software (ss. 276-295). Hershey: IGI Global. doi: 10.4018/978-1-4666-8499-7.ch011. 